\title{
Gallery of Chairs: A Word or Two from Some Education Division Chairs
} Adapted from the SLA Conference Slide Presentation by Maya Kucij

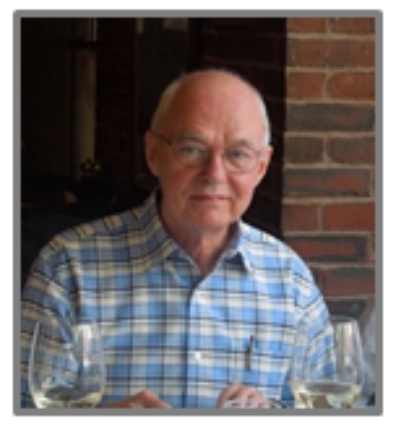

\author{
"I was at the SLA Board meeting where \\ the Division was approved. I recall \\ that Board member Shirley Eckleman \\ ( $s p$ ?) whose mike was on was heard to \\ say to the colleague next to her ${ }^{2} \mathrm{O} h$ \\ God, it's that Boston crowd \\ again." But we prevailed and moved \\ out of the Social Sciences Division, of \\ which we had been a subdivision, as I \\ recall."
}

\section{Malcolm Hamilton, DEDU Chair 1975-1976}

Editor of Education Libraries, 1976-1980

Boston Chapter President, 1987/88

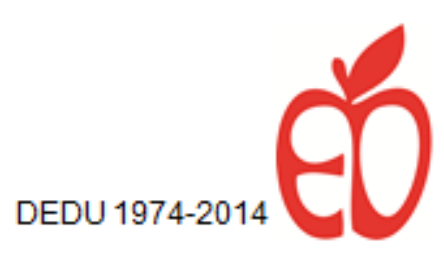

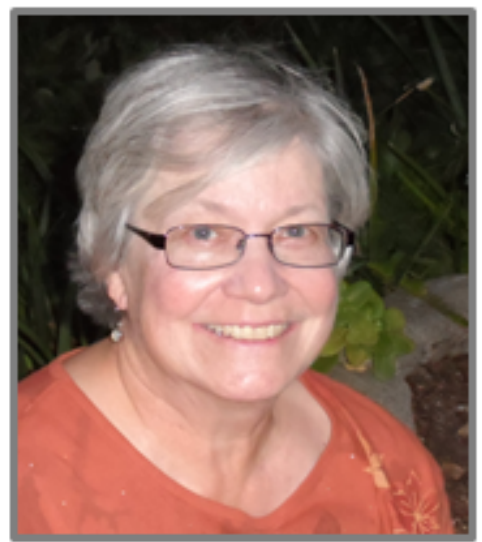

Janet Williams, DEDU Chair 1984-1985

Currently a School Librarian in South Africa
${ }^{a} M y$ first SLA conference in NYC I met Lois Renter, the librarian at ACT, our rival institution, as I was working for ETS, then Educational Testing Service. She was very kind and helpful. She shared a lot of librarian tips and introduced me to other librarians she thought might be of help. She accompanied me to a wonderful Swiss restaurant for dinner where we shared cheese fondue. She gave me her phone number, in case I had more questions. She could not have been nicer. I have found special librarians to be incredibly helpful and sharing, many going beyond the required question to find relevant data and assist their colleagues. ${ }^{*}$ 


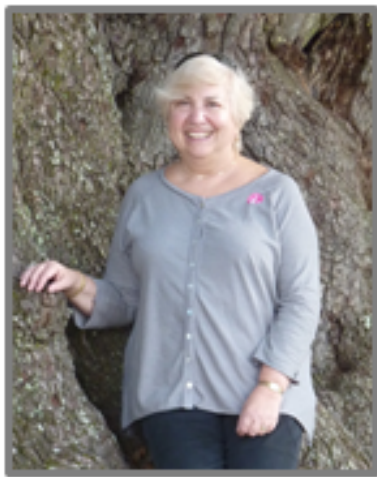

Maxine Goldsmith, DEDU Chair 1992-1993
"I have been a member of SLA for more than 40 years-

- I'm really not that old! I initially joined the organization when my first boss, Jean Guasco, director of the McGraw-Hill Library in NYC and an active SLA member, convinced me that SLA was the best professional organization with which to become involved. She most definitely was right and for that I will always be grateful.

In 1978 when I became librarian at the $N$ Department of Higher Education and for more than 25 years afterwards, I aligned myself with the Education Division. Through this small but mighty group I made many professional and personal contacts. This helped tremendously since like so many others in our profession, I ran a small operation with few resources at hand. E-mail and the internet were in beginning stages, sol relied on this cadre of individuals, several of whom are still close friends today."

\section{DEDU 1974-2014}

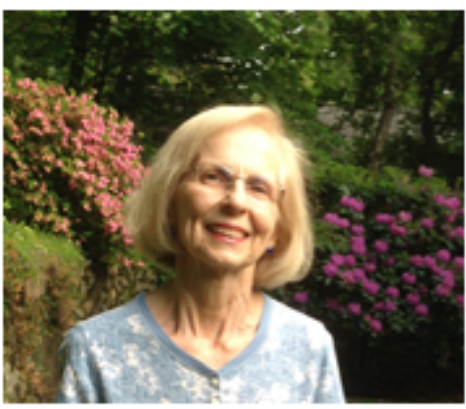

\section{Gladys Dratch}

DEDU Chair 1993-1994,

Recipient of the Anne Galler Award for Professional

Excellence, 1998
"At Simmons I had a wonderful course with Jim Matarazzo. He was very enthusiastic about SLA and that was what led me to the Boston Chapter of SLA. I cannot say enough about the collegiality of the Boston Chapter and my years of membership in SLA.

Following my first position at Hellenic College, I worked for more than 22 years as Head of Collection Development at the Gutman Library at the Harvard Graduate School of Education. These years were years of growth and excitement working with faculty and developing the collection in the field of Education...

I retired in the spring of 2008 , [but] I must tell you that I continue to be a member of SLA! I've had so many fulfilling experiences being a member of this organization that I like to keep in touch with friends and the organization that gave me so many opportunities to grow and be productive among my peers in the field of librarianship."

DEDU 1974-2014 


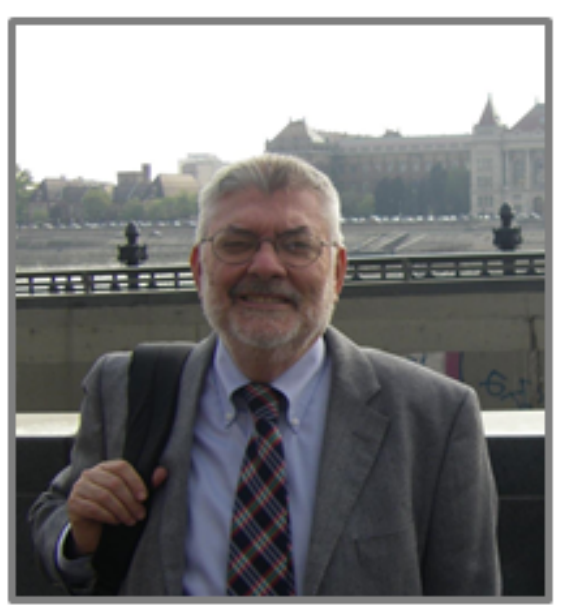

John D'Amicantonio, DEDU Chair 1995-1996, 2000-2001

Information Resource Officer for the U.S. Department of State Recipient of the Anne Galler Award for Professional Excellence, 2004
"I joined SLA when I was a library science student at Catholic $U$. I really got involved when I found the education division and worked with some of the nicest people on the planet. I have very fond memories of many truly professional and hard working individuals in the division."

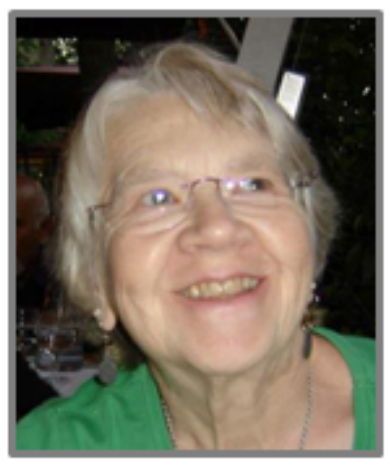

Debbie Bogenschutz, DEDU Chair, 1997-1998, 2011

Recipient of Anne Galler Award for Professional Excellence, 2001
"I feel really honored that the Education Division twice choose me to lead the division, and honored me with the Anne Galler Award for Professional Excellence. Coming from a community/technical college, with a small hard-working staff, the interaction with librarians from universities, education-specific libraries, and the various special libraries that make up the Education Division was an extremely valuable experience." 


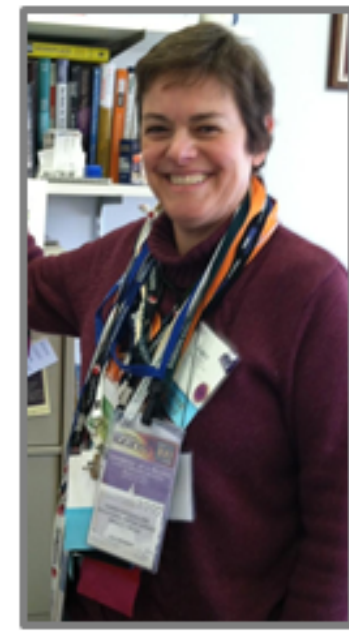

Karen McQuillen, DEDU Chair 1998-1999 Recipient of the Anne Galler Award for Professional Excellence, 2005
${ }^{4}$ One of my favorite conferences was the one in Minneapolis in 1999. I was Chair that year, and I worried for weeks prior to the event as to whether they'd go well and would be well received -- I even had a friend of mine read my Tarot cards with that question in mind. Thankfully, the card reading was positive and the presentations went off without a hitch! It was a great opportunity to learn leadership skills before being a leader in "real work".

Overall, the thing I like most about the Education Division is the opportunity to network which such a great group of people who understand the type of work I do and are always willing to help."

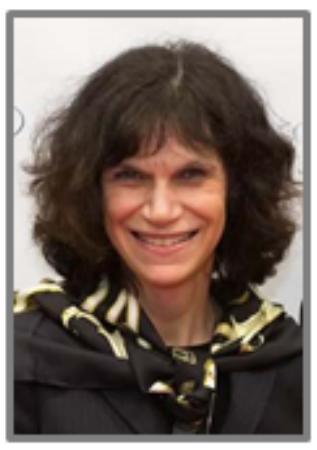

Jacqueline Snider, DEDU Chair 1999-2000, Recipient of the Anne Galler award for

Professional Excellence, 2011

Senior Manager of the Information Resource Center at ACT
DEDU 1974-2014

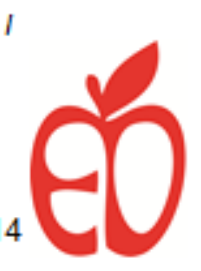

"When I attended my first SLA conference 1994 in Atlanta, I stumbled into the board meeting on Sunday. Gladys Dratch, Anne Galler, John D'Amicantonio and others were conducting business. Instead of making me feel like at interloper, Gladys stopped the meeting, warmly welcomed me, and set the tone for the Division from then on. Hergraciousness and warmth represented what the Divisions means. When I asked Gladys how I could become involved, she did everything she could to include me. Eventually I became editor of the Bulletin, chair, and now Education Libraries editor with some other postings in between." 


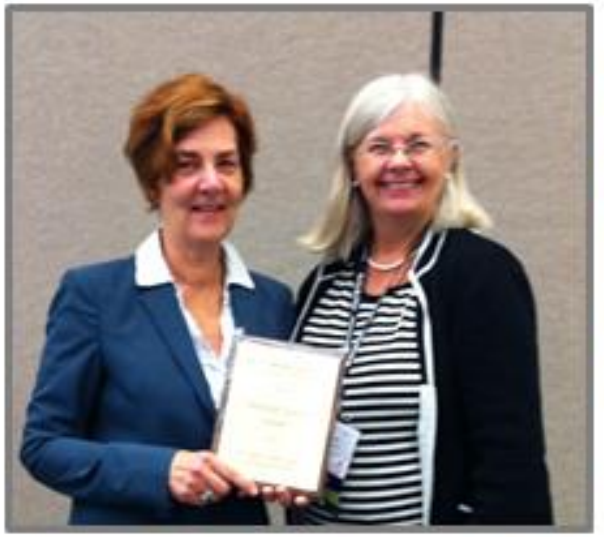

"The Education Division of SLA has always provided me with a synergistic group which has furthered my career and developed my professional networks. An added benefit has been to gain long lasting and deep friendships over the years. Education Division has been a place, virtually and physically, to share ideas, ask for advice, volunteer to be a speaker or member of a committee. I believe the Education Division is and has been an invaluable resource in my professional life."

\section{Deborah Garson (left) with Lesley Farmer}

\section{DEDU Chair 2002-2003,}

Recipient of the Anne Galler Award for Professional Excellence, 2013

Head of Research and Instruction Services Lecturer on Education Monroe C. Gutman Library Harvard University

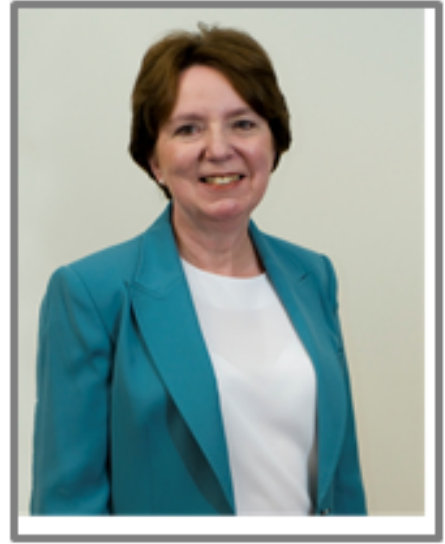

Sharon Weiner, DEDU Chair 2007-2008

Professor of Library Science and W. Wayne Booker Chair in Information Literacy Purdue University Libraries
"Through DEDU, I was able to meet colleagues in other education libraries with whom I could discuss common interests and develop collaborative projects. One of the most important projects was a special issue of Teachers College Record published in 2010 (\#112) that several of us co-edited. We proposed a new field of inquiry with a name that I coined: "education informatics."

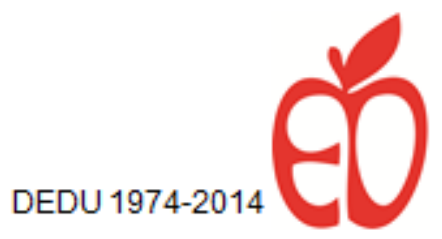




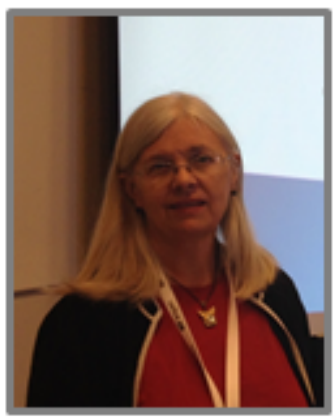

${ }^{4} I$ was invited to join the Education Division by John D'Amicantonio when I started working at California State University Long Beach. From the beginning, people were very welcoming, and eager to have me participate. The Education Division is a great venue for networking and contributing, and I have certainly benefited from it."

\section{Lesley Farmer,}

DEDU Chair 2008 \& 2013

Editor, Education Libraries, 2003-2007

Chair, Advanced Studies in Education and Counseling Professor, Educational Technology \& Media Leadership Coordinator, Librarianship Program California State University, Long Beach
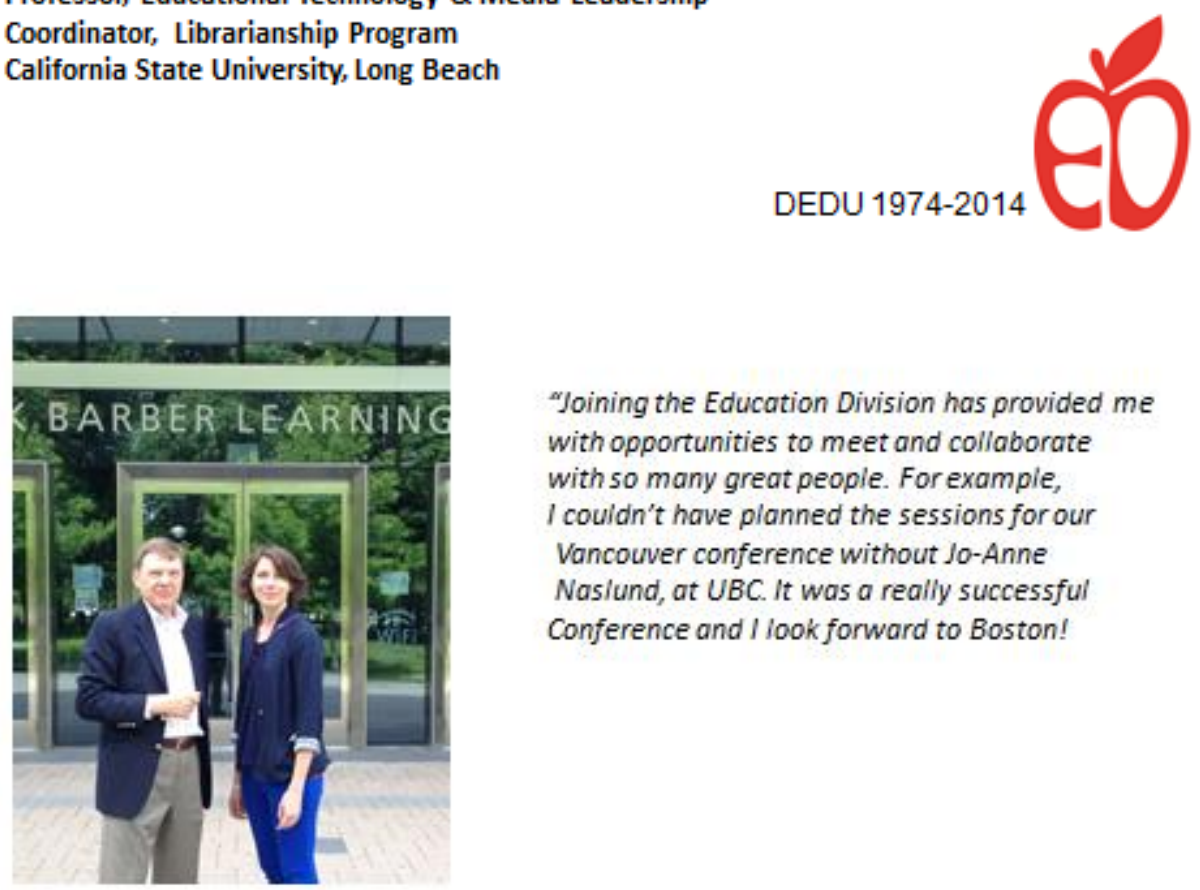

"Joining the Education Division has provided me with opportunities to meet and collaborate with so many great people. For example, I couldn't have planned the sessions for our Vancouver conference without Jo-Anne Nas/und, at UBC. It was a really successful Conference and l look forward to Boston!

\section{Maya Kucij with David Schumaker, DEDU Treasurer}

\section{DEDU Chair 2014}

Coordinator, Education Curriculum ResourcesCentre Liaison Librarian, Faculty of Education McGill Universty

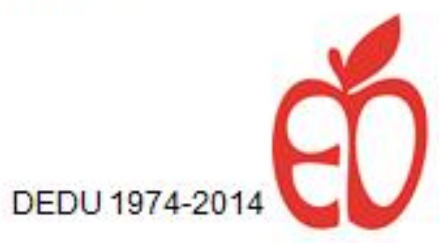

